\title{
METODE DILALAH AL-ALFADZ DALAM HUKUM ISLAM
}

\author{
H.M. Mawardi Djalaluddin
}

Fakultas Syariah dan Hukum Universitas Islam Negeri (UIN) Alauddin Makassar

\begin{abstract}
Dalalat 'like the (expression) nash is a hint of meaning fast form can be understood from him, as well as intended by the arrangement lafadz, either lafadz arrangement was intended for the original meaning or as meaning that followed it, in this case not the original meaning. Cues al-nash is not immediately understood the meaning of lafadzs and is not intended by its structure, but the meaning is understood from the cue al-nash is a common meaning for meaning can be understood from lafadz immediately. in this case to understand the meaning assigned by lafadz through iltizam way. Muwafaqah understand the law that is not called or legal texts lafzh in accordance with the law referred to in manthuq or lafzh nash. Understand al-mukhalafat is a law that is not known or understood from lafadz nash, in contrast to a law called the manthuq or lafadz nash, both in istbat and nafy.
\end{abstract}

\section{Keywords:}

Method dilalah Al-Alfadz, Islamic Law

\begin{abstract}
Abstrak
Dalalat 'ibarat (ungkapan) nash adalah petunjuk dari bentuk makna yang cepat dapat dipahami dari padanya, serta dimaksudkan oleh susunan lafadznya, baik susunan lafadz itu dimaksudkan untuk makna asli atau karena makna yang mengikutinya, dalam hal ini bukan makna asli. Isyarat al-nash adalah makna yang tidak segera dipahami dari lafadz-lafadznya dan tidak pula dimaksudkan melalui susunannya, akan tetapi makna yang dipahami dari isyarat al-nash adalah makna yang lazim bagi makna yang segera dapat dipahami dari lafadznya. dalam hal ini memahami makna yang ditunjuk oleh lafadz melalui cara iltizam. Mafhum Muwafaqah yaitu hukum yang tidak disebut atau hukum yang dipaham dalam lafzh nash sesuai dengan hukum yang disebut dalam manthuq atau lafzh nash. Mafhum al-mukhalafat adalah hukum yang tidak disebut atau yang dipahami dari lafadz nash, berbeda dengan hukum yang disebut dalam manthuq atau lafadz nash, baik dalam istbat maupun nafy.
\end{abstract}

Kata Kunci:

Metode Dilalah Al-Alfadz, Hukum Islam 


\section{A. PENDAHULUAN}

$\mathrm{B}$ erbicara tentang ibarat al-nash dan isyarat al-nash serta mafhum muwafaqah dan mafhum mukhalafah, berarti berbicara tentang dalalat. Dikatakan demikian karena hal tersebut merupakan bagian dari pembahasan tentang dalalat. Dalalat secara umum diartikan sebagai petunjuk memahami sesuatu atas sesuatu. dalam istilah lain dalalat diartikan sebagai sesuatu yang dikehendaki oleh lafadz ketika diucapkan secara mutlak, atau sesuatu pengertian yang ditunjuki oleh lafadz.

Al-Qur'an dan al-Hadits sebagai sumber hukum, memberikan berbagai pengertian yang digali dari berbagai dalalat lafadz-lafadz-nya. Menurut ulama Hanafiyah, sebagai pedoman untuk menggali dan memahami lafadz-lafadz al-nash tersebut dapat dilakukan dengan melalui pemahaman dalalat al-lafadz dan dalalat ghair al-lafadz. Oleh ulama Hanafiyah membagai dalalat al-lafdzi dibagi kepada empat macam yang berbeda tingkatannya, yaitu: ibarat al-nash, isyarat al-nash, dalalat al-nash dan iqtidha' al-nash. Sedangkan menurut ulama Syafi'iyah dapat dilakukan dengan melalui pemahaman dalalat al-manthuq dan dalalat al-mafhum. Oleh ulama Syafi'iyyah dalalat mafhum dibagi kepada dua macam, yaitu; mafhum muwafaqah dan mafhum mukhalafah.

Di dalam makalah ini penulis membatasi pembahasan pada masalah dalalat lafdzi dan pembagiannya menurut Metode Hanafiyah, dalam hal ini ibarat al-nash dan isyarat al-nash. Disamping itu, makalah ini juga akan membahas masalah masalah dalalat dan pembagiannya menurut Metode Mutakallimin, dalam hal ini dalalat mafhum muwafaqah dan mafhum mukhalafah.

\section{B. PEMBAHASAN IBARAT AL-NASH DAN ISYARAT AL-NASH \\ 1. Ibarat al- Nash (Ungkapan Nash)}

Ulama ushul al-fiqh mendefinisikan 'Ibarat al-Nash secara beragam. Namun beberapa defenisi yang dikemukan oleh para ulama, pada dasarnya ibarat al-nash merupakan upaya memahami makna dari lafadz. Oleh karena itu, ibarat al-nash disebut juga dengan istilah dalalah al-nash. ${ }^{1}$ Defenisi-defenisi tentang ibarat al-nash yang dikemukakan oleh para ulama, antara lain sebagai berikut :

a. Menurut Abu Zahrah bahwa ibarat al-nash adalah

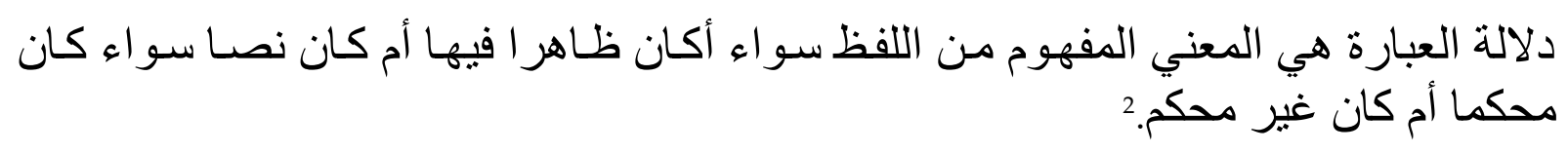

Artinya:

Dilalat 'ibarat adalah makna yang dapat dipahami dari lafzh; baik itu lafzh al-Zhahir atau lafzh al-nash, atau baik lafzh muhkam atau bukan muhkam.

${ }^{1}$ Lihat, Amir Syarifuddin, Ushul Fiqh 2 (Cet. I; Jakarata: Logos Wacana Ilmu, 1999), h. 130.

${ }^{2}$ Lihat, A. Djazuli, Ushul al-Fiqh: Metodologi Hukum Islam (Cet. I; Jakarta : Raja Grafindo Persada, 2000), h. 280. 
b. Menurut Syekh al-Khudlary bahwa ibarat al-nash:

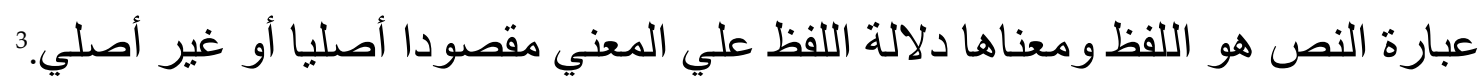

Artinya:

Ibarat al-Nash itu lafzh dan artinya adalah petunjuk lafzh atas makna yang dimaksudkan; baik yang dimaksudkan itu makna asli atau bukan asli.

c. Menurut 'Abd al-Wahhab Khallaf bahwa ibarat al-nash adalah:

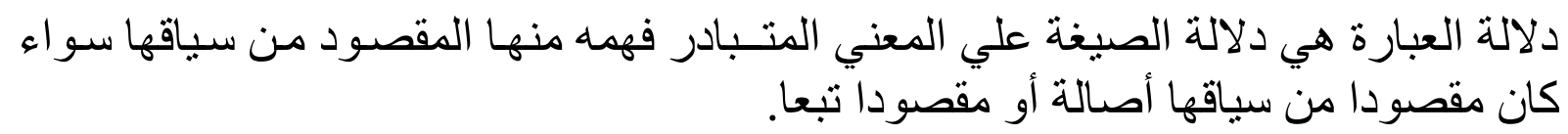

Artinya:

Dalalat 'ibarat (ungkapan) ialah petunjuk dari bentuk makna yang cepat dapat dipahami dari padanya, serta dimaksudkan oleh susunan lafadznya. Baik susunan lafadz itu dimaksudkan untuk makna asli atau karena makna yang mengikutinya (bukan makna asli). ${ }^{4}$

d. Menurut Zakiy al-Din Sya'ban:

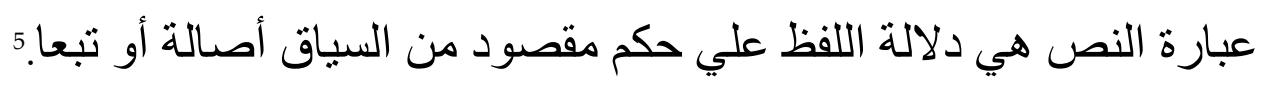

Artinya:

Ibarat al-nash adalah petunjuk lafzh atas hukum yang dimaksudkan it asli atau karena mengikuti hukum asli.

Dengan demikian, dapat dipahami bahwa pada dasarnya ibarat al-nash mempunyai kriteria sebagai berikut:

1. Mengandung lafadz yang tersusun dari dua makna maksud hukum; maksud hukum asli (hukum yang mula-mula dipakai) dan maksud hukum bukan asli (taba'iy =ikutan)

2. Mengandung makna yang segeta dapat dipahami dari susunan lafznya.

3. Diantara lafzhnya mengandung lafzh al-Zhahir, lafzah al-nash, lafzhal-muhkam atau lafzh ghayr al-muhkam.

Dalam konteks tersebut, dipahami pula bahwa yang dimaksud dengan ibarat alnash adalah sighatnya yang terdiri dari berbagai satuan kata (mufradat) dan kalimat. Sedangkan yang dimaksud dengan makna yang dipahami dari ibarat nash adalah makna yang dapat dipahami dari sighat itu sendiri, dalam hal ini adalah susunan kalimatnya.

Dalam kaitannya dengan hal tersebut, contoh lafadz 'ibarat al-nash dapat dilihat أحل الله البيع وحرم الربوا : dalam firman Allah QS. al-Baqarah (2) ayat 275, yang berbunyi (Allah telah menghalalkan jual-beli dan mengharamkan riba). Ibarat al-nash dalam

\footnotetext{
${ }^{3}$ Lihat, Ibid.,. Lihat pula, Khairul Uman, Ushul al-Fiqh II (Cet. II; Bandung : Pustaka Setia, 2001), h. 3.

${ }^{4}$ Lihat, Abd. Wahaf Khallaf, Ilmu Ushul al-Fiqh, alih bahasa oleh Moh. Zuhri (Cet. I; Semarang: Toha Putra, 1994), h. 212.

${ }^{5}$ Lihat, A. Djazuli, op.cit., h. 281.
} 
ayat ini menunjukkan kepada dua arti: yakni arti asli dan bukan asli (taba'iy). Arti asli yang dapat dipahami dari Ibarat al-nash ayat ini ialah bahwa jual beli tidak sama dengan riba. Arti ini dikatakan sebagai arti asli karena mula ayat-ayat ini dimaksudkan untuk membantah anggapan orang yang mengatakan bahwa jual beli itu sama dengan riba. Sebagaimana yang dijelaskan oleh ungkapan ayat sebelumnya yang berbunyi انما البيع مثل الربا (Sesungguhnya jual-beli itu sama dengan riba)

Sedangkan arti bukan asli yang dapat dipahami dan ibarat al-nash ayat ini ialah bahwa hukum jual-beli adalah halal dan hukum riba adalah haram. Arti ini dikatakan sebagai arti bukan asli karena merupakan arti lain; yakni meniadakan persamaan antara jual-beli dengan riba, serta menjelaskan hukum masing-masing.

\section{Isyarat al-Nash}

Berbeda dengan ibarat al-nash, isyarat al-nash adalah makna yang tidak segera dipahami dari lafadz-lafadznya dan tidak pula dimaksudkan melalui susunannya. Akan tetapi makna yang dipahami dari isyarat al-nash adalah makna yang lazim bagi makna yang segera dapat diphami dari lafadznya. itu artinya bahwa memahami makna yang ditunjuk oleh lafadz melalui cara iltizam. Oleh karena kelazimannya terkadang jelas dan terkadang tersembunyi (baca; tidak jelas), maka sesuatu yang diisyaratkan oleh nash kadangkala pemahamannya membutuhkan penalaran yang mendetail dan pemikiran yang sistematis. ${ }^{6}$ Dengan demikian, isyarat al-nash adalah dalalah nash terhadap makna yang lazim bagi sesuatu yang dipahami dari ibaratnya. Dalam hal ini tidak dimaksudkan dari susunannya, akan tetapi pemahamannya membutuhkan kontemplasi pemikiran atau analisis sistematis.

Dalam kaitan tersebut, berbagai defenisi Isyarat al-nash telah banyak dikemukakan oleh para ulama ushul fiqhi, antara laian sebagai berikut:

a. Menurut 'Abd al-Wahab Khallaf:

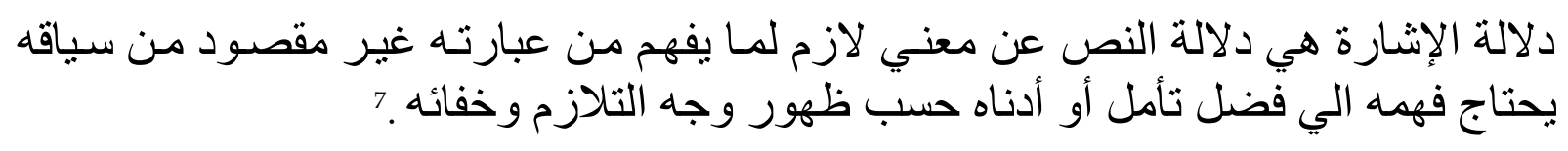

Artinya:

Dilalat isyarat adalah petunjuk nash atau makna yang lazim (tetap) yang dapat dipahami dari ungkapannya serta tidak dimaksudkan oleh susunan lafznya dan untuk memahami (makna)-nya diperlukan pemikiran sedalam-dalamnya atau pemikiran yang sederhana, menurut terang dan tidaknya dari segi ketetapannya.

b. Menurut Syekh al-Khudlairy:

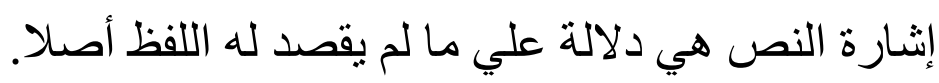

Artinya:

Isyarat al-nash adalah petunjui nash atau makna yang tidak dimaksudkan oleh lafznya

\footnotetext{
${ }^{6}$ Lihat, Abd. Wahab Khallaf, op.cit., h. 214.

${ }^{7}$ Lihat, Wahbah al-Zuhaeli, al-Wasith fi Ushul al-Fiqh (Dimasyqy: al-Mathba'ah al-Ilmiah, 1969), 324.
} 
menurut makna aslinya". ${ }^{8}$

c. Menurut Zakiya al-Din Sya'ban:

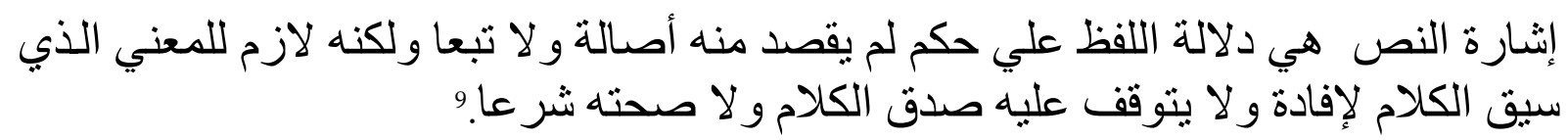

Artinya:

Isyarat al-nash adalah petunjuk lafzh atas hukum yang tidak dimaksudkan baik oleh makna asli maupun makna tabi'iy (bukan asli). Akan tetapi hukum itu tetap ada bagi makna yang tersusun (dalam) susunan lafz untuk keperluannya, dan tidak dapat diketahui atas makna hukum itu suatu kebenaran dan keshasihan susunan lafzh menurut syara'.

d. Menurut Abu Zahrah:

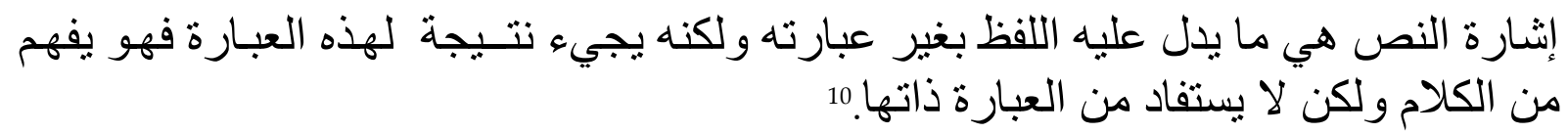

Artinya:

Isyarat al-Nash adalah suatu makna yang ditunjuki oleh lafzh bukan dari segi "ibaratnya. Akan tetapi ia muncul sebagai natijat (konklusit) dari ibarat ini ia dapat dipahami dari susunan kalimat, tetapi tidak memberikan faedah dari zat (hakikat makna yang tersurat didalam) 'ibarat-nya'.

Dengan demikian, isyarat al-nash pada dasarnya mempunyai ciri-ciri sebagai berikut:

1. Mengandung makna (hukum) tetap yang tidak dimaksudkan baik oleh makna asli maupun makna taba'iy dalam susunan lafznya.

2. Dalam memahaminya kadang-kadang diperlukan pemikiran sedalam-dalamnya atau pemikiran yang sederhana mungkin.

3. Kebenaran dan keshasihan makna (hukum) dari Isyarat al-nash ini tidak dapat diketahui dalam tuntutan syara'.

Kaitannya dengan isyarat al-nash, sebagai contoh dapat dilihat dalam QS. alNisa: 3 yang berbunyi : فأن خفتم ألا تعدلوا فواحدة (Maka jika kamu takut tidak akan dapat berlaku adil, maka (kawinlah) seorang saja). Ibarat al-nash dalam ayat ini dapat dipahami bahwa tidak halal bagi seorang laki-laki baik menurut agama maupun peradilan, untuk menikahi isteri lebih dari satu apabila ia meyakini tidak dapat berbuat adil di antara isteri-isterinya. Sedangkan dari Isyarat al-nash-nya dapat dipahami bahwa berbuat adil itu wajib selamanya, baik itu laki-laki ketika beristeri satu atau ketika berbilang isteri, karena berbuat aniaya terhadap isteri adalah haram

\footnotetext{
${ }^{8}$ Lihat, A. Djazuli, op.cit., h. 285.

${ }^{9}$ Lihat, Ibid.,

${ }^{10}$ Lihat, Ibid.,
} 
hukumnya. ${ }^{11}$

\section{MAFHUM MUWAFAQAH DAN MAFHUM MUKHALAFAH}

\section{Mafhum Muwafaqah}

Ulama Syafi'iyah umumnya, mendefenisikan mahf'um al-muwafaqat sebagai berikut:

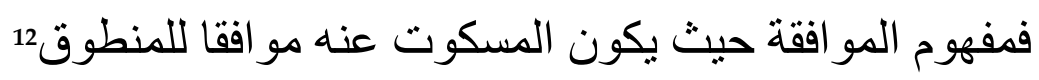

Artinya :

Mafhum al-muwafaqat yaitu dimana (hukum) yang tidak disebut (yang dipaham dalam Lafzh nash) sesuai dengan (hukum) yang disebut (dalam manthuq)lafzh(nash)".

Dalam kaitannya dengan hal tersebut, ulama Syafi'iyah membagi mafhum almuwafaqat ini kepada dua bagian yaitu:

a. Lahn al-khitab; yaitu Illat hukum dalam manthuq nash yang disebut sama pantasnya untuk menerapkan pada peristiwa yang tidak disebutkan hukumnya oleh suatu lafadz nash. Lahn al-khitab ini juga disebut dengan istilah mafhum almusawi. ${ }^{13}$

b. Fahwa al-khitab; yaitu illat hukum pada peristiwa yang tidak disebutkan dalam mantuq nash lebih pantas (utama) untuk diterapkan pada peristiwa yang disebut hukumnya oleh suatu lafadz dalam mantuq nash. Fahwa al-khitab ini juga disebut dengan istilah mafhum aulawi. ${ }^{14}$

\section{Mafhum mukhalafat}

Ulama Syafi'i mendefenisikan mafhum al-mukhalafat ini sebagai berikut:

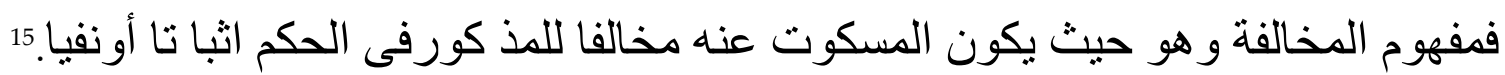

Artinya:

Mafhum al-mukhalafat yaitu dimana (hukum) yang tidak disebut (yang dipahami dari lafas nash) berbeda dengan (hukum) yang disebut (dalam manthuq) lafzh nash, baik dalam istbat maupun nafy.

Dalam kaitannya dengan hal tersebut, para ulama ushul fiqh dari kalangan Syafi"i tersebut menamakan mafhum al-mukhalafat ini dengan dalail al-khitab, sebagai

${ }^{11}$ Lihat, Ibid., h. 286

${ }^{12}$ Lihat, A. Djazuli, op.cit., h. 312.

13 Contoh Lahn al-khitab firman Allah QS. al-Nisa : 4 yang artinya : Bahwasanya orang-orang ygmemakan harta anak yatim secara aniya, sesungguhnya ia telah memakan api neraka dalam perutnya. Mantuq ayat ini bahwa haram memakan harta anak yatim secara aniaya, akan tetapi dibalik mantuq dipahami bahwa meniadakan harta anak yatim itu dapat dilakukan dengan memakan secara aniaya dan membakar. Dengan demikian, membakar harta anak yatim sama hukumnya dengan memakan harta anak yatim secara aniaya. Itu artinya bahwa hukum yang tersirat kekuatannya sama dengan hukum yang tersurat.

${ }^{14}$ Contoh mafhum aulawi atau fahwa al-khitab firman Allah dalam QS. al-Isra' : 23 yang artinya : jangan kamu mengucapkan kepada orang tuaтu kata-kata uf dan janganlah kamu membentak keduanya. Oleh karena itu, memukul orang tua hukumnya haram sebagaimana haramnya mengucapkan kata-kata uf kepadanya.

${ }^{15}$ Lihat, Abd. Wahab Khallaf, op.cit., 
contoh firman Allah dalam surat al-An'am (6):145, yang berbunyi :

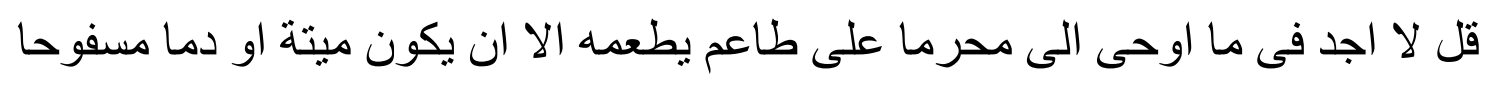

Artinya:

katakanlah: "Tiadalah aku peroleh dalam wahyu yang diwahyukan kepadaku, suatu yang diharamkan bagi orang-orang yang hendak memakannya kecuali kalau makanan itu bangkai atau darah yang mengalir.

Dilihat dari manthuq ayat di atas, bahwa darah yang mengalir adalah haram. Sedangkan darah yang tidak mengalir sebagai faham yang berbeda atau faham kebalikan dari manthuq ayat tersebut adalah halal. Dalam hal ini tidak dapat diperoleh petunjuk dari manthuq ayat tersebut atas halalnya darah yang tidak mengalir. ${ }^{16}$

Demikian pula dalam QS. al-Baqarah (2) ayat 197 yang berbunyi: الحج اشهر معلومـات (musim haji adalah beberapa bulan dimaklumi bulan Syawal, Zulqaidah dan Zulhijjah). Dilihat manthuq ayat ini bahwa ibadah haji itu bisa dilakukan pada bulan-bulan tertentu yakni bulan Syawal, Zulqa'dah dan Zulhijjah. Adapun paham mahfum al-mukhalafat, bila ibadah haji tersebut dilakukan di luar bulan-bulan yang telah ditentukan, maka tidak boleh karena hal ini berlawanan dengan manthuq alnash tersebut.

Kendatipun demikian, mafhum mukhalafah yang dapat diterima adalah harus memenuhi syarat-syarat sebagai berikut:

1. Mafhum al-mukhalafat itu tidak bertentangan dengan dalil yang lebih kuat, baik dalil manthuq bih maupun mafhum al-muwafaqat. ${ }^{17}$

2. Petunjuk lafadz yang disebutkan bukan dimaksudkan untuk menguatkan sesuatu keadaan. ${ }^{18}$

${ }^{16}$ Lihat, A. Djazuli, op.cit., h. 315

${ }^{17}$ Contoh mafhum al-mukhalafat yang bertentangan dengan dalil manthuq bih QS. al-Isra (17) : 31 yang berbunyi : ولا تقتلو ا ولادكم خشية املاق (Janganlah kamu bunuh membunuh anak-anakmu karena takut miskin). Dari ayat ini dapat dipahami bahwa membunuh anak sendiri karena tidak takut miskin adalah boleh. Akan tetapi hal ini bertentangan dengan QS. al-Isra' ayat: 33 yang melarang membunuh jiea kecuali karena ada alasan yang benar. Dengan demikian mafhum al-mukhalafat seperti di atas tidak memnuhi syarat karena bertentangan dengan manthuq bih. Sedangkan contoh mafhum al-mukhalafat yang bertengan dengan mafhum al-muwafaqatnya yaitu bahwa mengucapkan perkataan selain "ah" atau "uf" antara lain seperti penganiayaan kepada orang tua adalah boleh. Akan tetapi mafhum al-mukhalafat seperti ini bertentangan dengan mafhum al muwafaqatnya yaitu bahwa jika mengucapkan "ah" saja itu haram karena ucapan itu menyakitkan orang tua, maka apalagi seperti penganiayaan kepada orang tua. Karena penganiayaan itu lebih menyakitkan lagi. Dengan demikain mahfum almukhalafat seperti ayat di atas tidak memenuhi syarat karena bertentangan dengan mahfum al-muwafaqat.

18 Sebagai contoh sabda Rasulullah SAW yang mengatakan bahwa barang siapa beriman kepada Allah dan hari akhir berkatalah yang baik atau diam dan barang siapa yang beriman kepada Allah dan khari akhir maka hormatilah tetangganya). Dari hadis ini dapat di ambil mafhum al-mukhalafatnya yaitu bahwa orang-orang yang tidak beriman kepada Allah dan hari akhir boleh berkata yang tidak baik atau mengganggu tetangganya. Akan tetapi mafhum mukhlafat seperti ini tidak memenuhi syarat karena maksud hadis ini menerangkan bahwa orang yang beriman itu di samping ia memang beriman kepada Allah dan hari akhir juga dituntut untuk berkata baik dan menghormati tetangga merupakan penguat bagi orang yang beriman. Dengan demikian seandainya petunjuk lafadz itu bukan dimaksudkan untuk menguatkan orang yang beriman niscaya dapat di ambil mafhum al mukhalafatnya. 
3. Petunjuk lafadz yang disebutkan dalalat al-manthuq bukan suatu hal yang biasanya terjadi. ${ }^{19}$

4. Petunjuk lafadz yang disebutkan (dalalat al-manthuq) harus berdiri sendiri, tidak mengikuti kepada yang lain. ${ }^{20}$

5. Petunjuk lafadz yang disebutkan (dalalat al-manthuq) bukan dimaksudkan untuk kejadian atau perisitiwa khusus. ${ }^{21}$

Petunjuk lafadz yang disebutkan dalalat al-manthuq bukan dimaksudkan untuk membatasi dengan sifat tertentu. ${ }^{22}$

Dalam konteks tersebut, mafhum mukhalafah dibagi kepada enam macam, yaitu:

1. Mahfum al-Washf (mafhum al-shifat), yaitu menetapkan lawan hukum bagi yang tidak disebutkan (maskut anhu) dari hukum yang disebutkan (manthuq bih) dengan memakai sesuatu sifat. ${ }^{23}$

2. Mafhum al-syarth, yaitu menetapkan lawan hukum bagi yang tidak disebutkan dari hukum yang tidak disebutkan dengan memakai sesuatu syarat. ${ }^{24}$

3. Mafhum al-ghayah, yaitu menatapkan lawan hukum bagi yang tidak disebutkan dari hukum yang disebutkan dengan memakai sesuatu batasan. ${ }^{25}$

${ }^{19}$ Sebagi contoh firman Allah dalam QS. al-nisa (4); 23 yang mengatakan bahwa diharamkan atas kamu menikahi anak-anak istrimu (anak-anak tirimu) yang ada dalam pemeliharaanmu. Dari ayat ini dapat di ambil mafhum al-mukhalafah-nya yaitu bahwa anak-anak tiri (anak-anak dari istri si suami) yang berada di luar pemeliharaan suami adalah halal untuk dinikahi. Akan tetapi mafhum al-mukhalafat seperti ini tidak memenuhi syarat karena menurut kebiasaannya anak tiri itu mengikuti ibunya dan sekaligus berada dalam pemeliharaan suami (bapak tiri). Jadi, pemeliharaan anak tiri di luar pemeliharaan suami itu bukan suatu hal yang biasa terjadi. Dengan demikian anak tiri yang berada di luar pemeliharaanya juga haram untuk dinikahi.

${ }^{20}$ Contoh firman Allah QS. al-Baqarah: 187 yang melarang mencampuri istri apabila seorang beri'tikaf di Mesjid. Mahfum mukhalafah dari ayat ini bahwa mencampuri isteri di luar mesjid yang sedang i'tikaf adalah boleh. Akan tetapi mafhum mukhalafah seperti ini tidak benar karena larangan mencampuri isteri dalam keadaan i’tikaf berdiri sendiri tidak dikaitkan dengan tempat.

${ }^{21}$ Sebagai contoh firman Allah dalam QS. Ali Imran: 130 yangm artinya: hai orang-orang yang beriman janganlah memakan riba dengan berlipat ganda. Dari ayat di atas dapat diambil mafhum al-mukhalafat bahwa riba yang berklipat ganda adalah halal. Akan tetapi mafhum al-mukhalafat seperti ini tidak memenuhi syarat karena penyebutan riba yang bersifat ganda dalam ayat tersebut dalam ayat tersebut dikhususkan peristiwa pada zaman jahiliyyah.

${ }^{22}$ Sebagai contoh firman Allah dalam QS. al-Nahl : 14 yang artinya : Allah menundukkan lautan agar kamu dapat memakan dari padanya daging yang segar. Dari ayat ini dapat diambil mafhum al-mukhalafatnya, yaitu bahwa memakan daging yang tidak segar adalah halal. Akan tetapi mafhum al-mukhalafat seperti ini tidak dapat memenuhi syarat karena penyebutan daging segar dalam ayat ini dimaksudkan untuk menggambarkan daging yang halal dimakan itu harus yang segar, jadi seandainya ayat ini bukan dimaksudkan untuk membatasi sifat " daging segar" maka tentu ayat itu dapat diambil mafhum al-mukhalafatnya.

${ }^{23}$ Contoh : firman Allah dalam QS. al-Nisa : 25 yang mengatakan bahwa barang siapa di antara kamu yang tidak mampu mengawini perempuan merdeka yang mukmin, maka ia boleh mengawini wanita beriman dari hamba sahaya yang ia miliki. Mafhum shifat dari ayat ini adalah tidak boleh menikahi hamba sahaya yang tidak mukmin. Lihat, Amir Syarifuddin, op.cit., h. 150.

${ }^{24}$ Contoh : Firman Allah dalam QS. al-Thalaq : 6 yang mengatakan bahwa perempuan yang ditalak dalam keadaanhamil, maka berilah nafkah sampai ia melahirkan. Mafhum syarath dari ayat ini bahwa tidak wajibnya memberi nafkah bagi perempuan yang ditalak tidak dalam keadaan hamil. Lihat, Ibid.,

${ }^{25}$ Contoh : Firman Allah dalam QS. al-Baqarah : 230 yang mengatakan bahwa : jika suami mentalak isterinya (talak tiga), tidak halal bekas isterinya itu untuknya hingga bekasisteri itu mengawini laki-laki lain. Mafhum ghayah dalam ayat ini adalah jika bekas isteri yang ditalak tiga telah kawin lagi dengan laki-laki lain, kemudian bercerai dan habis masa iddahnya, maka boleh mengawini bekas isteri yang telah ditalak tiga tersebut. Lihat, op.cit., h. 151. 
4. Mafhum al-adad, yaitu menetapkan lawan hukum bagi yang tidak disebutkan dari hukum yang disebutkan dengan memakai bilangan tertentu. ${ }^{26}$

5. Mafhum al-hasyr, yaitu menetapkan lawan hukum bagi yang tidak disebutkan dari hukum yang disebutkan dengan memakai pengkhususan secara terbatas. ${ }^{27}$

6. Mafhum al-laqab,yaitu menetapkan lawan hukum bagi yang tidak disebutkan dari hukum yang disebutkan dengan memakai suatu nama atau sebutan tertentu. ${ }^{28}$

\section{KESIMPULAN}

Dari uraian yang telah dikemukakan di atas, dapat disimpulkan, bahwa:

1. Dalalat 'ibarat (ungkapan) nash adalah petunjuk dari bentuk makna yang cepat dapat dipahami dari padanya, serta dimaksudkan oleh susunan lafadznya, baik susunan lafadz itu dimaksudkan untuk makna asli atau karena makna yang mengikutinya, dalam hal ini bukan makna asli.

2. Isyarat al-nash adalah makna yang tidak segera dipahami dari lafadz-lafadznya dan tidak pula dimaksudkan melalui susunannya, akan tetapi makna yang dipahami dari isyarat al-nash adalah makna yang lazim bagi makna yang segera dapat diphami dari lafadznya. dalam hal ini memahami makna yang ditunjuk oleh lafadz melalui cara iltizam.

3. Mafhum Muwafaqah yaitu hukum yang tidak disebut atau hukum yang dipaham dalam lafzh nash sesuai dengan hukum yang disebut dalam manthuq atau lafzh nash.

4. Mafhum al-mukhalafat adalah hukum yang tidak disebut atau yang dipahami dari lafadz nash, berbeda dengan hukum yang disebut dalam manthuq atau lafadz nash, baik dalam istbat maupun nafy.

${ }^{26}$ Firman Allah dalam QS. al-Nur : 2 yang mengatakan bahwa : pezina laki-laki dan perempuan, pukullah masing-masing $100 \mathrm{kali}$. Mafhum adad ayat ini adalah tidak sah pukulan terhadap pezina laki-laki danperempuan apabila lebihatu kurang dari 100 kali. Lihat, Ibid.,

${ }^{27}$ Firman Allah dalam QS. al-An'am :145 menetapkan bahwa makanan yang diharamkan hanya berlaku pada bangkai, darah yang mengalir, daging babi dan binatang disembelih atas nama selain nama Allah. Mafhum al-hasyrnya adalah makanan selaindari keempat yang disebutkan dalam ayat ini adalah halal kecuali ada nash lain yang mengharamkannya.

28 Contoh: Muhammad adalah Rasulullah. Artinya bhwditetapkan kerasulan seorang yang bernama Muhammad. Mafhum laqabnya adalah tidak berlakunya kerasulan bagi orang selain Muhammad bin Abdullah. Lihat, Ibid., 


\section{Daftar Pustaka}

Djazuli, A., Ushul Figh : Metodologi Hukum Islam, Cet. I; Jakarta : Raja Grafindo Persada, 2000.

Hasabullah, Ali, Ushul al- Tayri al- Islam, Kairo: Dar al- Ma'arif, 1964.

Khallaf, Abd. Wahaf, Ilmu Ushul al-Figh, alih bahasa oleh Moh. Zuhri, Cet. I; Semarang : Toha Putra, 1994.

Qardawi, Yusuf, al-Ijtihad fi al-Syari'at al- Islamiyat ma'a nazharatin Tahliyyat fi alIjtihad fi al-Mu'ashir, Kuwait: Dar al- Qalam, 1985.

Rasjidi, M., Keutamaan Hukum Islam, Cet. II, Jakarta: Bulan Bintang, 1980.

Syarifuddin, Amir, Ushul Figh 2, Cet. I; Jakarata : Logos Wacana Ilmu, 1999.

Uman, Khairul, Ushul al-Figh II, Cet. II; Bandung : Pustaka Setia, 2001.

Zuhaeli, Wahbah, al-Wasith fi Ushul al-Fiqh, Dimasyqy : al-Mathba'ah al-Ilmiah, 1969. 